\title{
Aggiornamento and Dialogue: Some Ambiguity from Gaudium et Spes
}

Lucas Briola

At the heart of ecclesial mission is a diligent reading, discernment, and elevation of the signs of the times in the light of Jesus Christ. Such was the imperative of the Second Vatican Council's Pastoral Constitution on the Church in the Modern World, Gaudium et spes, that has today been freshly received by Pope Francis. Following the aggiornamento of the Council, Lumen et Vita's own call for papers used words and phrases like "enter into relationship," "listen," "hear," "discern," and, yes, "dialogue." Indeed, precisely in order to attentively listen to those yearnings of the world, the word of the Council and Francis's pontificate has been dialogue. Meanwhile, alongside excitement and hope, confusion and controversy continue to surround the legacies of both the Council and Francis.

This paper suggests that one of the issues-under-the-issues is the exact meaning of "dialogue," an ambiguity that can be traced back to Gaudium et spes itself. After considering the positions of Joseph Ratzinger and Edward Schillebeeckx vis-à-vis Gaudium et spes, this paper claims that two conceptions of dialogue are present in the church's pastoral constitution. This conciliar ambiguity surrounding "dialogue" — whether a bold, one-sided kerygmatic proclamation of the Gospel or a more reciprocal, two-sided mutual learning - is undoubtedly one source of confusion in any discussion of ecclesial mission and thus merits our further attention. This paper proposes that three fundamental theological questions offer some aid to resolve this key tension: the relationship of nature and grace; the role of eschatology in ecclesiology; and the identity and locus of the church. To continue to receive the Council's teaching on dialogue is essential — the church's missionary mandate from Christ depends on it. 
Contemporary scholars of the Council rightly recognize dialogue as a centerpiece of Vatican II's teaching. After all, by my count, the word "dialogue" appears at least 42 times in ten of its sixteen documents. ${ }^{1}$ John O'Malley sees dialogue as one of the "words of reciprocity" that capture the Council's collaborative spirit. ${ }^{2}$ Very recently, Richard Gaillardetz names "the ecclesial habit of dialogical engagement" as the second of his seven "pillars of Vatican II's ecclesial vision."3 Massimo Faggioli likewise highlights the Council's dialogical shift with modernity and the "two-way learning process [it evinced]: the society on one side and the church on the other side." ${ }^{4}$ The litany could continue; suffice it to say, however, that much of contemporary scholarship stresses this dialogical core as well as the mutual, two-way learning between church and world it suggests.

One of the most influential theologians of the Council and its reception, Edward Schillebeeckx, confirmed this reading of dialogue during the Council. In Rome, on September 16, 1964, two days after the opening of the Council's third session, Schillebeeckx delivered a lecture entitled "Church and World." ${ }^{\prime 5}$ little more than a month later, debate would open on the schema that would become Gaudium et spes. In this lecture, the Dutch theologian took seriously Vatican II's post-ghetto, more positive mentality, speaking of the world's "implicit christianity,"

\footnotetext{
${ }^{1}$ This is taken from the English translations of the Council's documents from the Vatican website (GS: 12, UR: 12, AG: 6, PO: 3, NA: 2, GE:2, OT: 2, LG: 1, AA: 1, and DH: 1).

${ }^{2}$ John W. O’Malley, What Happened at Vatican II (Cambridge, MA: Harvard University Press, 2008), 50, 204.

${ }^{3}$ Richard R. Gaillardetz, An Unfinished Council: Vatican II, Pope Francis, and the Renewal of Catholicism (Collegeville, MN: Liturgical Press, 2015), 54-57.

${ }^{4}$ Massimo Faggioli, A Council for the Global Church: Receiving Vatican II in History (Minneapolis, MN: Fortress Press, 2015), 194.

${ }^{5}$ Edward Schillebeeckx, "Church and World," published World and Church (New York: Sheed and Ward, 1971), 96-114. Originally a lecture given at the opening of the new building of the Dutch Documentation Centre for the Council in Rome, it first appeared in print as "Ker ken wereld" in Tijdschrift voor Theologie 4 (1964): 286-399.
} 
that "distinctive, non-sacral, but sanctified expression of man's living community with the living God"; meanwhile, the church was "the 'set aside', sacral expression of this implicit Christianity." Dialogue takes place between these "two complementary forms of experience of the one Christianity," implicit (world) and explicit (church). ${ }^{7}$ Accordingly, Schillebeeckx prioritizes attentive listening in the church's dialogical relationship to the world. He writes:

A church in monologue with herself is not a partner. If she does not listen to the world, she will disregard as much human knowledge, influenced by anonymous grace, as there are people outside her institutional boundaries or outside her hierarchy. If, on the other hand, she does listen, attentively but critically... she will not hear strange sounds coming from outside, but will recognize the voice of her own Lord, who is not only head of the church, his body, but is also Lord of the 'world.'8

For Schillebeeckx and many others, Vatican II's aggiornamento was marked by this more twosided ecclesial stance towards the world.

Nevertheless, another influential conciliar theologian, Joseph Ratzinger, famously strident in his critique of Gaudium et spes, countered the above reading of dialogue. While, like others, Ratzinger praised the Council's rhetorical shift away from authoritative "creeds of obligation" and "anathemas of negation," he offered a distinction between pronouncement and dialogue. Instead of a two-sided dialogue, the German theologian preferred a simple "proclamation of the Gospel - thus opening up the faith to the non-believer and abdicating all claim to authority other than the intrinsic authority of God's truth, manifesting itself to the hearer

\footnotetext{
${ }^{6}$ Schillebeeckx, "Church and World," 101.

${ }^{7}$ Schillebeeckx, "Church and World," 102. Emphasis original.

${ }^{8}$ Schillebeeckx, "Church and World," 105.
} 
of the message." 9 As he would write elsewhere, "The core of the Church's task, the message about Jesus Christ as Savior and Redeemer, as such cannot be undertaken by the Church in the form of a dialogue; in the end it can only be preached. The kerygma remains in this sense the distinctive linguistic form of the Church, for which it is responsible before others." 10 In this case, since the Gospel is not "an object of negotiation", dialogue meant the inevitable translation involved in this kerygmatic proclamation. For Ratzinger, the adequacy of Gaudium et spes's final formulation of dialogue remained an "open question."

This paper agrees that Gaudium et spes (GS) did indeed leave the precise meaning of dialogue an open question. Both notions of dialogue suggested by Schillebeeckx (more twosided) and Ratzinger (more one-sided) can be found in the constitution. This should hardly be surprising; Richard Gaillardetz and Catherine Clifford have highlighted the inherently juxtapositional nature of the Council's final texts. ${ }^{11} \mathrm{~A}$ few, non-exhaustive examples will suffice.

The Constitution's very first mention of "dialogue" evinces the more kerygmatic, onesided understanding of dialogue amenable to Ratzinger's concerns: the church will "enter into dialogue with the whole human family about all these various problems, throwing the light of the Gospel on them and supplying humanity with the saving resources which the church has received from its founder under the promptings of the Holy Spirit" (GS 3). ${ }^{12}$ Here, the church learns little

\footnotetext{
${ }^{9}$ Joseph Ratzinger, Theological Highlights of Vatican II (New York: Paulist Press, 2009), 224-225.

${ }^{10}$ Joseph Ratzinger, Das neue Volk Gottes: Entwürfe zur Ekklesiologie (Düsseldorf : Patmos, 1969), 294. The translation comes from Joseph Komonchak.

${ }^{11}$ Richard R. Gaillardetz and Catherine E. Clifford, Keys to the Council: Unlocking the Teaching of Vatican II (Collegeville, MN: Liturgical Press, 2012), xv.

${ }^{12}$ My translations are taken from The Basic Sixteen Documents of Vatican Council II, ed. Austin Flannery (Northport, NY: Costello Publishing, 2007).
} 
beyond an attentiveness to the signs of the times; instead, dialogue entails proclaiming the Gospel in light of the world's deepest yearnings.

GS's second mention of dialogue - in its striking section on atheism — is more two-sided, though not quite Schillebeeckx's two-sided listening. While atheists should "weigh the merits of the Gospel of Christ with an open mind," the church is challenged to bear more authentic witness to the Gospel (GS 21) since "Believers can...have more than a little to do with the rise of atheism" (GS 19). ${ }^{13}$ In light of these shortcomings, Christians accordingly are challenged to live out a more Christian Christianity. In this case, dialogue involves the humble learning that comes from honest self-appraisal, all the while remaining cognizant of the distinctive and definitive answer the church offers in the Gospel. This same sentiment can be found later: "The church is guardian of the deposit of God's word and draws religious and moral principles from it, but it does not always have a ready answer to every question. Still, it is eager to associate the light of revelation with the experience of humanity in trying to clarify the course upon which it has recently entered" (GS 33). Humility and an openness to learning are complemented by an awareness of the distinctive singularity of the church's message.

The closest that Gaudium et spes comes to two-sided mutual dialogue is found in the constitution's fourth chapter. The first subsection speaks of the "Mutual Relationship of Church and World." The Council is aware both that the church "is to be a leaven and, as it were, the soul of human society in its renewal by Christ and transformation into the family of God" and that "there is a great variety of help that [the church] can receive from the world in preparing the

\footnotetext{
13 The modi's objections to the ecclesial sin implied in this section were rejected. See Joseph Ratzinger, "Introductory Article and Chapter 1: The Dignity of the Human Person," in Commentary on the Documents of Vatican II (vol. 5), general ed. Herbert Vorgrimler (New York: Herder and Herder, 1969), 157.
} 
ground for the Gospel...” (GS 40). It should be said that while chapter four devotes fourteen paragraphs to what the church offers the world, it devotes only three to what the church "receives" from the world. ${ }^{14}$ Nevertheless, this section approaches Schillebeeckx's understanding of dialogue. The church, the entire people of God, "profits from the experience of the past ages, from the progress of the sciences, and from the riches hidden in various cultures," it has "learned...to express the christian message in the concepts and languages of different peoples and tried to clarify it in the light of the wisdom of their philosophers," it is called "to listen to and distinguish the many voices of our times and to interpret them in the light of God's word, in order that the revealed truth may be more deeply penetrated, better understood, and more suitably presented," it "acknowledges gratefully that...it has been helped in various ways by people of all classes and conditions," and finally it "recognizes that it has benefited and is still benefiting from the opposition of its enemies and persecutors" (GS 44).

GS concludes with a final optimistic exhortation for the church to eagerly embark in dialogue so that "people all over the world will awaken to a lively hope, the gift of the holy Spirit, that they will one day be admitted to the haven of surpassing peace and happiness in their homeland radiant with the glory of the Lord" (GS 92-93). Nevertheless, despite this indispensability of dialogue in ecclesial mission, this paper has shown the ambiguity inherent in GS's actual use of dialogue, torn between Schillebeeckx's two-sided mutuality and Ratzinger's one-sided bold, kerygmatic proclamation.

\footnotetext{
${ }^{14}$ This division of paragraphs is taken from the French (and thus original) version of Gaudium et spes found on the Vatican website.
} 
To conclude this examination and suggest a basis for further progress, there are at least three pertinent questions at hand. First, how do we relate nature and grace? Joseph Komonchak has perceptively noted the post-conciliar tensions between neo-Thomism and neoAugustinianism. ${ }^{15}$ Does grace permeate the world, enabling the world to contribute to the church? Or, does the grace offered by the church break through and redirect a depraved nature, deserving a stridently bold kerygmatic proclamation of the Gospel? In this light, GS 36 speaks of nature's "rightful autonomy," and yet an autonomy never separated from the God of Jesus Christ.

Second, what roles do history and eschatology play in the life of the church? How realized is one's ecclesial eschatology? One of the most significant ecclesiological innovations of the Council's Dogmatic Constitution on the Church, Lumen gentium (LG), was its retrieval of the eschatological nature of the church. ${ }^{16}$ This conciliar insight undergirds both the ecclesial humility and magnanimity GS espouses. ${ }^{17}$ On one hand, the church, as a pilgrim in history, "at once holy and always in need of purification, follows the path of penance and renewal" (LG 8). This eschatologically less realized ecclesial vision that stresses the "not-yet" indicates a church that can and must learn from the world. On the other hand, LG asserts the participation of the earthly church in the heavenly church (LG 50). This eschatologically more realized ecclesial vision that

\footnotetext{
${ }^{15}$ See Joseph Komonchak, “Augustine, Aquinas, or the Gospel sine glossa?", in Unfinished Journey: The Church 40 Years after Vatican II: Essays for John Wilkins, ed. Austin Ivereigh (New York: Continuum, 2005), 102-118. This paper is indebted to the work, especially this essay, of Komonchak.

${ }^{16}$ For instance, the initial preparatory schema De Ecclesia paid minimal attention to the eschatological dimensions of the church (see Joseph Komonchak's translation at https://jakomonchak.files.wordpress.com/2013/07/draft-of-deecclesia-chs-1-11.pdf). What would become chapter seven of Lumen gentium, "The Pilgrim Church," would only be inserted between the Council's second and third sessions.

${ }^{17}$ See Richard R. Gaillardetz, "Vatican II and the Humility of the Church," in The Legacy of Vatican II, eds. Massimo Faggioli and Andrea Vicini (New York: Paulist Press, 2015), 87-108.
} 
stresses the "already" indicates a church that is indeed the definitive realization of God's plan for humanity, a realization meant to shed light on a dark world.

Third, who and where is the church? ${ }^{18}$ Both Schillebeeckx's claim of the presence of an explicit and implicit Christianity and Ratzinger's criticism of GS's "deeply-rooted extrinsicism" that sharply divided church and world ${ }^{19}$ challenge a clean demarcation of a discrete "church" in dialogue with a discrete "world." On one hand, if the church is understood as the visible Catholic Church, the Gospel can simply be proclaimed to the "non-church." On the other hand, if "church" is more ambiguous - as the language of degrees of incorporation in LG 15-16 suggests —and extends beyond its visible boundaries, the visible church can certainly learn more about the God of Jesus Christ from "the world."

These questions are complex. At the very least, I hope I have militated against two tendencies that I see too frequently. On one hand, an unreflective use of "dialogue" runs the risk of being co-opted by meanings foreign to Christianity. On the other hand, a reactive dismissal of dialogue betrays both the letter and spirit of the Council and post-conciliar papacies. Instead, "dialogue" deserves further pause and discernment, particularly in the three questions with which I concluded, in our own teaching, ministries, and living out of baptismal vocations. Perhaps it even warrants a dialogue! ${ }^{20}$

\footnotetext{
${ }^{18}$ See Joseph A. Komonchak, Who Are the Church? (Milwaukee: Marquette University Press, 2008).

${ }^{19}$ Ratzinger, "Introductory Article and Chapter 1: The Dignity of the Human Person," 119: "The Church meets its vis-à-vis in the human race, for example in non-Christians, unbelievers, etc. But it cannot stand outside the human race, and even for reasons of dialogue it cannot exclude itself from the human race and then artificially create a solidarity which in any case is the Church's lot. The lack of understanding shown in this manner by those who drafted the text can probably only be attributed to the deeply-rooted extrinsicism of ecclesiastical thought, to long acquaintance with the Church's exclusion from the general course of development and to retreat into a special little ecclesiastical world from which an attempt is then made to speak to the rest of the world."

${ }^{20}$ The feedback and comments from Christopher Ruddy, Benjamin Hohman, and Justin Petrovich have greatly improved this article.
} 